\title{
Reconstruction of upper anterior by implant using customized zirconia abutment and all ceramics: a clinical report
}

\author{
Ja-Yeong Kim", Jae-Min Seo ${ }^{2 *}$ \\ 'Department of Dentistry, Presbyterian Medical Center, University of Seonam College of Medicine, Jeonju, Republic of Korea \\ ${ }^{2}$ Department of Prosthodontics, School of Dentistry and Institute of Oral Bio-Science, Chonbuk National University, Jeonju, \\ Republic of Korea
}

It is so hard to obtain optimal anterior esthetics in the implant prosthesis. This is not only because of hard and soft tissue problem such as alveolar bone resorption and interdental papilla loss but also because of prosthetic limitation related to marginal exposure of metal abutment and metal ceramics and low transillumination. In this case, guided soft tissue healing is obtained using a long term provisional restoration with soft and hard tissue augmentation or immediate implantation. Then, this healed tissue is transferred to final master model using a customized impression coping and the implant is restored with a customized zirconia abutment and a all ceramics. This case presents satisfying result esthetically and functionally. (J Dent Rehabil Appl Sci 2014;30(1):81-92)

Key words: all ceramics; customized impression coping; customized zirconia abutment; implant

\section{서 론}

Brånemark이 임플란트를 치과 영역에 소개한 이래로 임플란트 치료는 치과 치료의 한 분야로서 점점 중요성 이 강조되고 있다. 그러나 임플란트 주위 조직은 치아 주 위 조직과 달라 연조직의 형태를 예측하기 힘들고, 염증 이 발생할 경우에 치근단측으로 더 급속히 확산하게 된 다. ${ }^{1}$ 따라서, 심미성이 매우 중요한 전치부 임플란트의 경우, 이와 관련된 합병증이 발생할 수 있어 치료과정에 많은 노력이 필요하다. 본 증례에서는 상악 전치부에 임 플란트를 식립하여 심미적, 기능적으로 만족할 만한 결 과를 얻었기에 이를 보고하고자 한다.

*Correspondence to: Jae-Min Seo, DDS, MSD Department of Prosthodontics, School of Dentistry and Institute of Oral Bio-Science, Chonbuk National University, 664-14 Dukjin-dong, Dukjin-gu, Jeonju, 561-756, Republic of Korea

Tel: +82-63-250-2696, Fax: +82-63-250-2218, E-mail: jmseo@jbnu.ac.kr Received: January 4, 2014/Last Revision: January 20, 2014/Accepted: March 9 , 2014
증례 보고

\section{1. 증례 1}

1) 환자 개요 및 치료 계획

상기환자는 51세 여자 환자로 상악 좌측 중절치 및 우 측 중절치를 지대치로 한 2단위 금속도재관에서 냄새가 난다는 것을 주소로 내원하였다. 임상적, 방사선학적 소 견상 상악 우측 중절치의 심한 치근우식과 치근단 농양 이 있었으며 치관부쪽 순측 치조골이 흡수된 상태였다 (Fig. 1).
Copyright@ 2014 The Korean Academy of Stomatognathic Function and Occlusion. (c) It is identical to Creative Commons Non-Commercial License. 

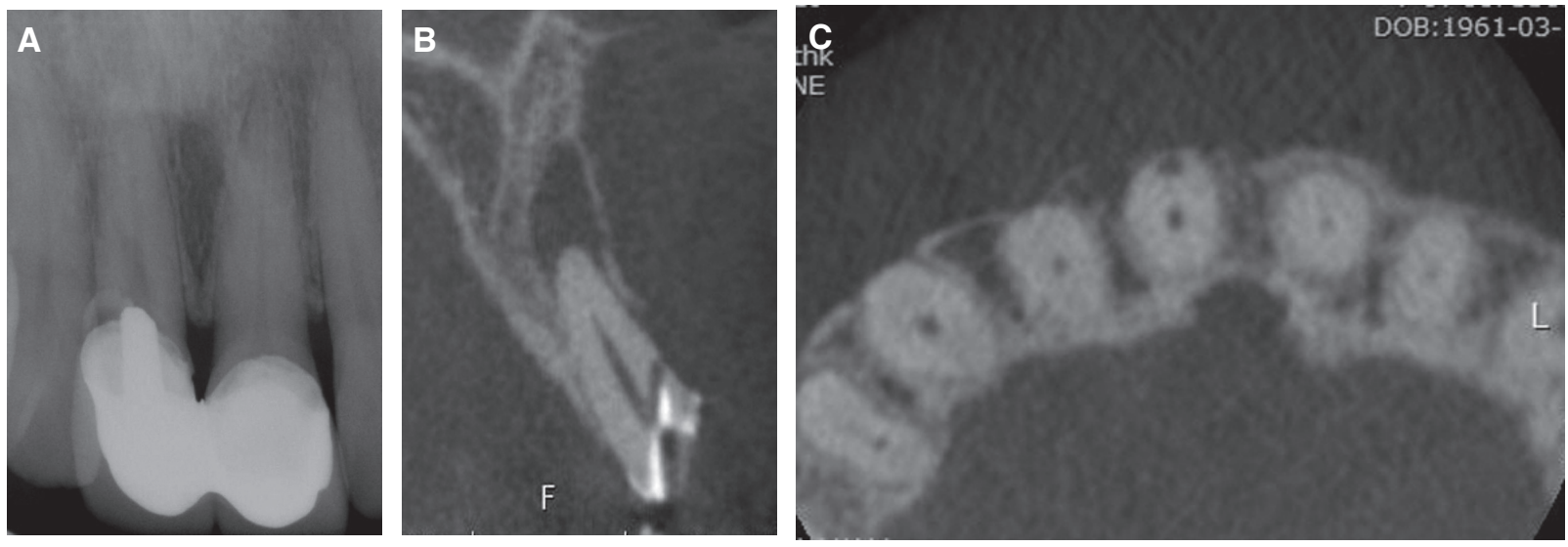

Fig. 1. Pre-operative radiographic image. (A) Periapical standard radiographic image, (B) Sagittal view on cone beam computed tomography (CBCT), (C) Transverse view on CBCT.
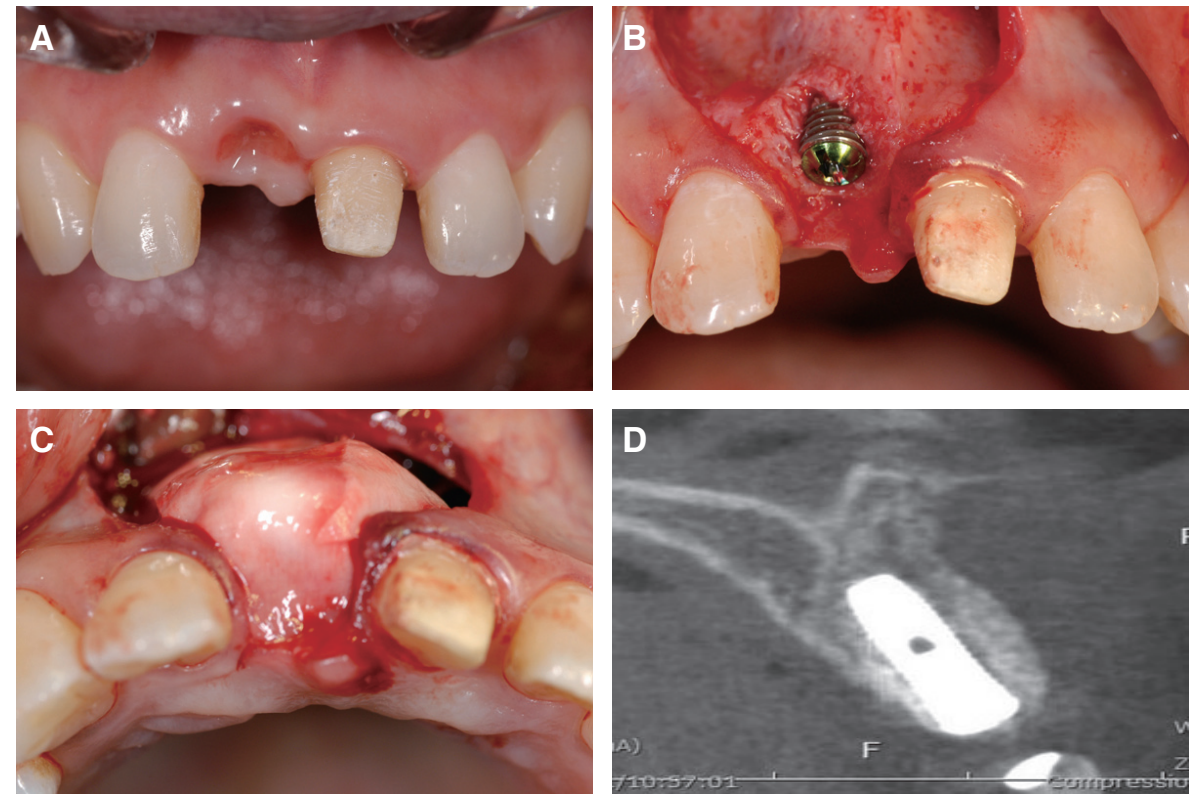

Fig. 2. Implant installation and postoperative radiographic image. (A) Pre-operation state, (B) Implant installation, (C) Guided bone regeneration (GBR), (D) Sagittal view on $\mathrm{CBCT}$.

상악 우측 중절치는 발치 후 골유도재생술을 동반한 임플란트를 식립하고, 추후 상악 좌, 우측 중절치를 전 부도재관을 이용해 수복하기로 계획하였다.

\section{2) 임플란트 식립 및 골유도재생술}

상악 우측 중절치의 발치 6주 후, 소대절제술을 시행 하고 직경 $4.0 \mathrm{~mm}$, 길이 $12 \mathrm{~mm}$ 의 임플란트(Superline, Dentium, Seoul, Korea)를 식립하였다. 치관부쪽 순측 골결손부는 하악 우측 하악지에서 채취한 자가골과 이
종골(Bio-Oss, Geistlich, Wolhusen, Switzerland)을 $1: 1$ 로 혼합하여 적용하고 Fibrin glue (Tissel, Baxter AG, Vienna, Austria)을 이용하여 이식부를 고정하였으며 차 폐막(Bio-Gide, Geistlich)으로 덮어 골유도재생술을 시 행하였다(Fig. 2).

2차 수술 전까지 상악 좌측 중절치를 지대치로 한 cantilever 형태의 임시치아를 장착하여 우측 중절치의 대략적인 순측 치은 형태를 형성하고, 치간유두를 최대 한 유지시키려고 노력하였다. 
3) 2차 수술 및 임시 보철물 장착

임플란트 식립 6개월 후 2차 수술을 시행한 후, 즉시 인상채득을 하여 스크류 타입의 임플란트 임시 보철물 을 당일에 제작, 체결하였다. 임플란트 주변 연조직의 형태 평가 및 형성을 위해 주기적으로 내원하여 임시보 철물을 평가하고 조정하였다(Fig. 3).

4) 최종 보철물 완성 및 정기 검진

임시 보철물 장착 후 16 주에 최종 보철물을 위한 인
상을 채득하였다. 임시 보철물로 형성한 연조직의 형태 를 최종 모형 및 맞춤형 지르코니아 지대주에 재현하기 위해 맞춤형 인상 코핑을 제작하였다. 맞춤형 인상 코핑 은 Hinds ${ }^{2}$ 가 제안한 방법으로 임시 보철물의 상부를 퍼 티(ExaFlex Putty, GC, Tokyo, Japan)를 이용해 인상 채 득한 후, 이 인상체와 일반적인 인상용 코핑(Impression coping pick-up, Dentium)사이에 유동성 레진(UniFil Flow, GC)을 채워 제작하였다(Fig. 4).

최종 모형상에서 제작된 맞춤형 지르코니아 지대주
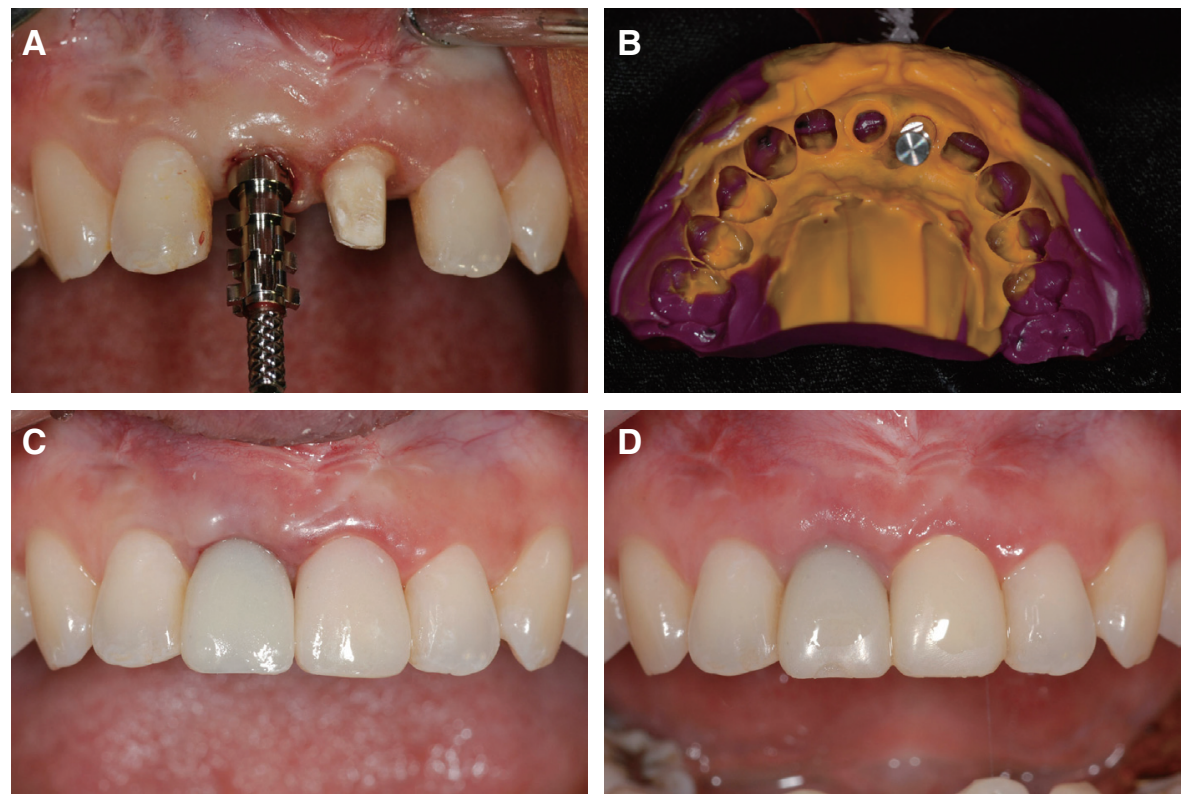

Fig. 3. Provisional restoration. (A) Impression coping connection, (B) Impression for provisional restoration, (C) Initial placement of provisional restoration, (D) 16 weeks after provisional restoration setting.
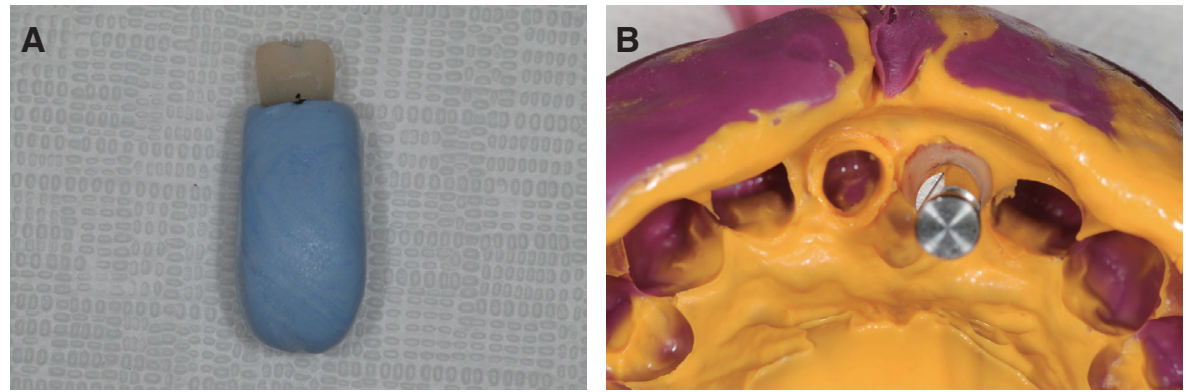

Fig. 4. Customized impression coping and final impression. (A) Placement of the provisional restoration connected with the analog into the putty container, (B) impression with customized impression coping for final restoration. 

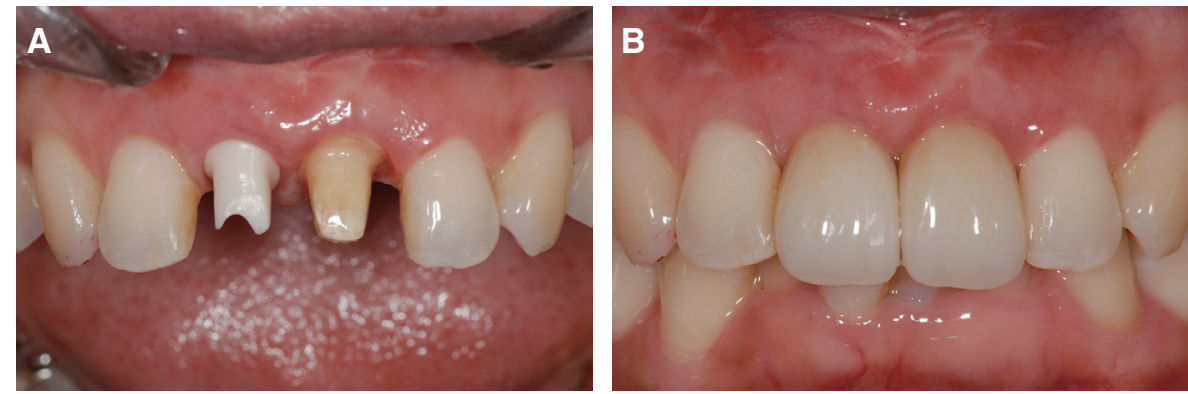

Fig. 5. Final restoration. (A) Connection of customized zirconia abutment, (B) Final restoration setting.

(Zirconia Myplant, Raphabio Co., Seoul, Korea)를 통 법에 따라 $30 \mathrm{Ncm}$ 의 힘으로 체결하고, 좌,우측 중절 치 모두 완전도재관(IPS e.max Press, Ivoclar Vivadent, Schaan, Liechtenstein)을 레진시멘트(RelyX Unicem, $3 \mathrm{M}$ ESPE, Seefeld, Germany)를 이용해 접착하였다(Fig. 5). 소대술을 시행한 부위에 연조직 반흔이 아직 남아있 으나, 순측 치은선이 인접치와 조화롭고 치간 유두가 치 간 공극을 $100 \%$ 채우고 있다. 또한 치아의 형태 및 색조 가 조화로워 환자가 기능적, 심미적으로 만족해하였다.

\section{2. 증례 2}

1) 환자 개요 및 치료 계획

본 환자는 외상으로 인해 상악 좌우측 중절치 및 좌측 측절치의 파절을 주소로 내원한 22세 남환이다. 임상적, 방사선적 소견상, 좌측 중절치는 치조정 부근의 수평 치 근 파절을 보여 근관치료 후 교정적 정출술을 권유하였 으나, 환자분은 임플란트를 이용한 치료를 원하였다. 이 에 좌측 측절치는 레진을 이용해 수복하고, 우측 중절치 는 근관치료 후 완전도재관을 제작하며, 좌측 중절치는 발치 후 즉시 임플란트 식립 후 완전도재관을 이용해 수 복하기로 계획하였다(Fig. 6).

2) 즉시 임플란트 식립 및 즉시 임플란트 임시보철물 체결

상악 좌측 중절치를 발거하고, 직경 $4.0 \mathrm{~mm}$ 길이 13 $\mathrm{mm}$ 의 임플란트(Full OSSEOTITE Tapered Certain, BIOMET 3i, Warsaw, IN, USA)를 즉시 식립하였다. 임 플란트 매식체와 잔존 협측골 사이의 빈 공간은 이종골 (Bio-Oss)로 채운 후 차폐막(Bio-Gide)을 덮어주었다 (Fig. 7).
임플란트 식립 직후 integration diagnostics (Osstell ${ }^{\mathrm{TM}}$ Mentor, Integration Diagnostics AB, Göteborg, Sweden) 을 이용해 implant stability quotient (ISQ) 값을 측정한 결과 68을 나타내어 임시 보철물을 바로 제작하였으며, 중심위 및 편심위에서 대합치와 교합되지 않도록 당일 조정하여 체결하였다(Fig. 8). 이는 Calandiello 등, ${ }^{3} 2003$ 년 Glauser 등, ${ }^{4}$ Bornstein 등 ${ }^{5}$ 과 Rodrigo 등 ${ }^{6}$ 이 연구한 바 즉시하중을 적용하는데 적절한 ISQ 수치였다. 16주 에 걸쳐 임시 보철물의 형태를 조금씩 조정하며 연조직 을 형성하였다.

\section{3) 최종 보철물 완성 및 정기검진}

임플란트 식립 및 임시보철물 장착 16주 후, 최종보철 을 위한 인상을 채득하였다. 임플란트 연조직 형태를 맞 춤형 지대주에 재현하기 위해 맞춤형 인상 코핑을 제작 하였다(Fig. 9).
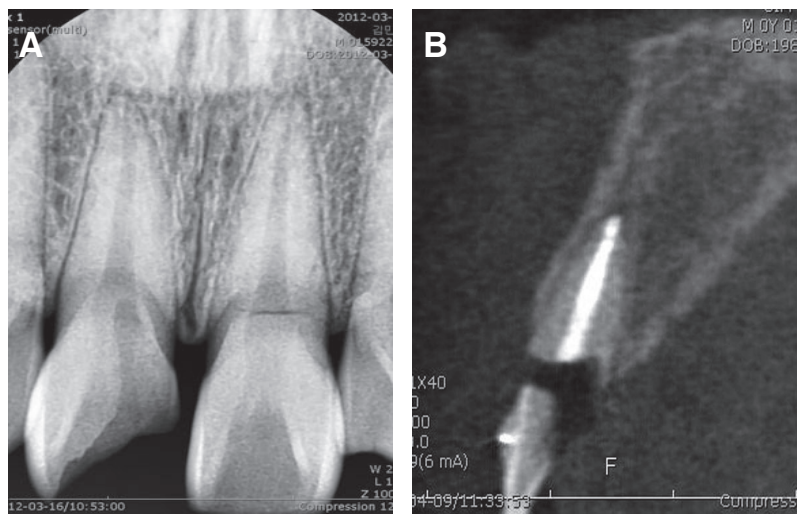

Fig. 6. Pre-operative radiographic image. (A) Periapical standard radiographic image, (B) Sagittal view on CBCT. 

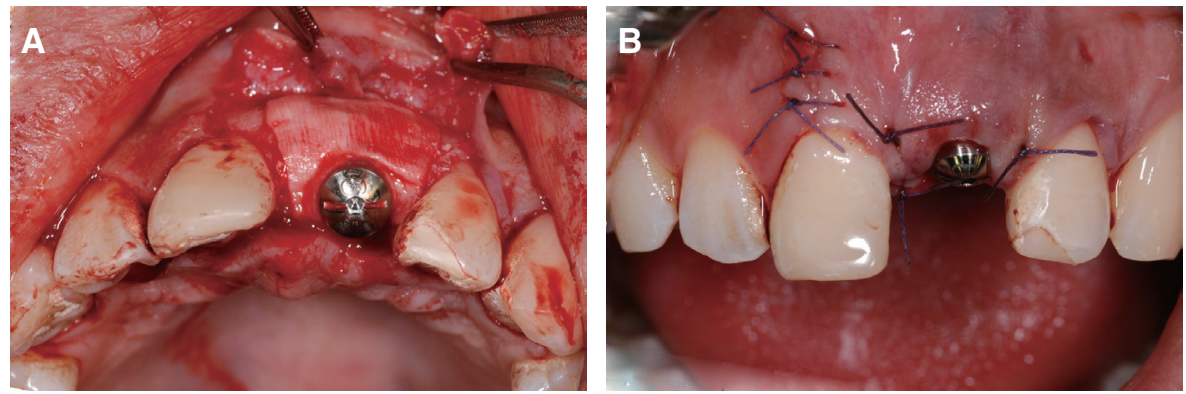

Fig. 7. Immediate implant installation. (A) Implant installation, (B) Closed primary suture.
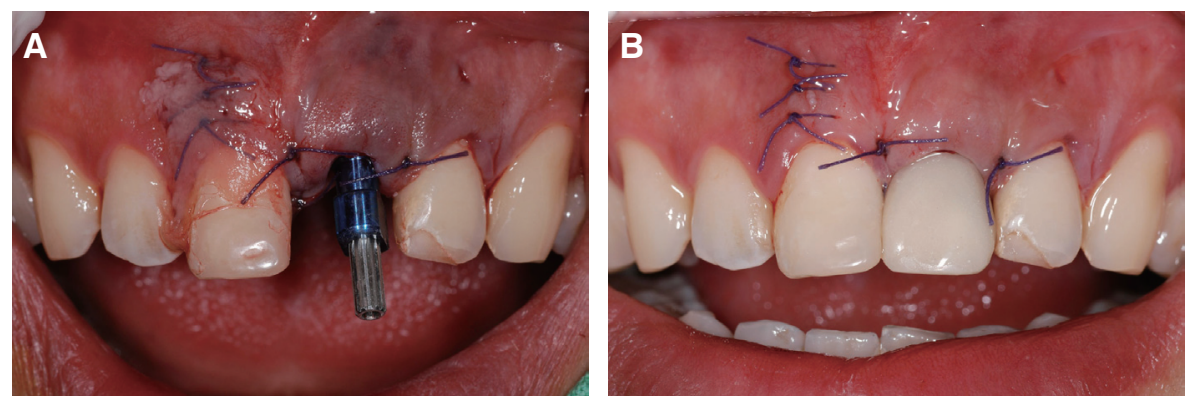

Fig. 8. Immediate provisional restoration. (A) Impression coping connection, (B) Initial placement of immediate provisional restoration.
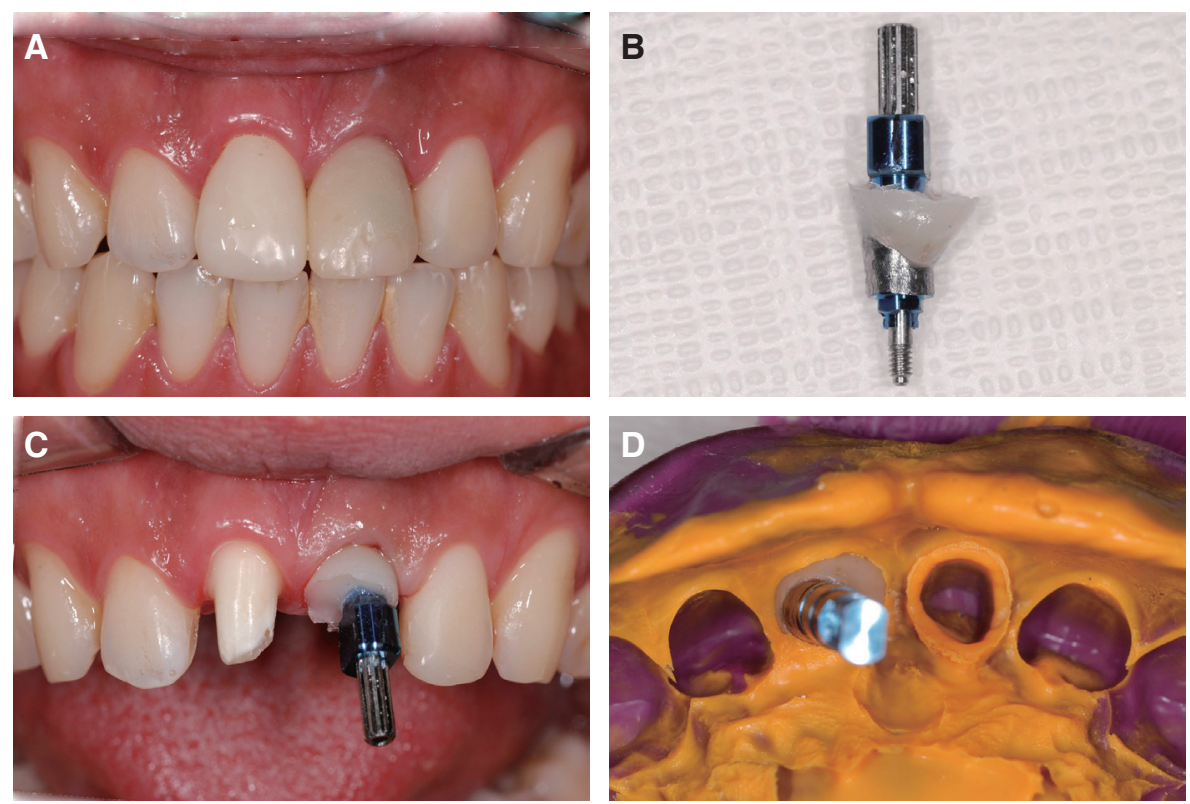

Fig. 9. Final impression taking. (A) 16 weeks after implant installation and implant provisional restoration setting, (B) Customized impression coping, (C) connection of customized impression coping, (D) impression with customized impression coping for final restoration. 

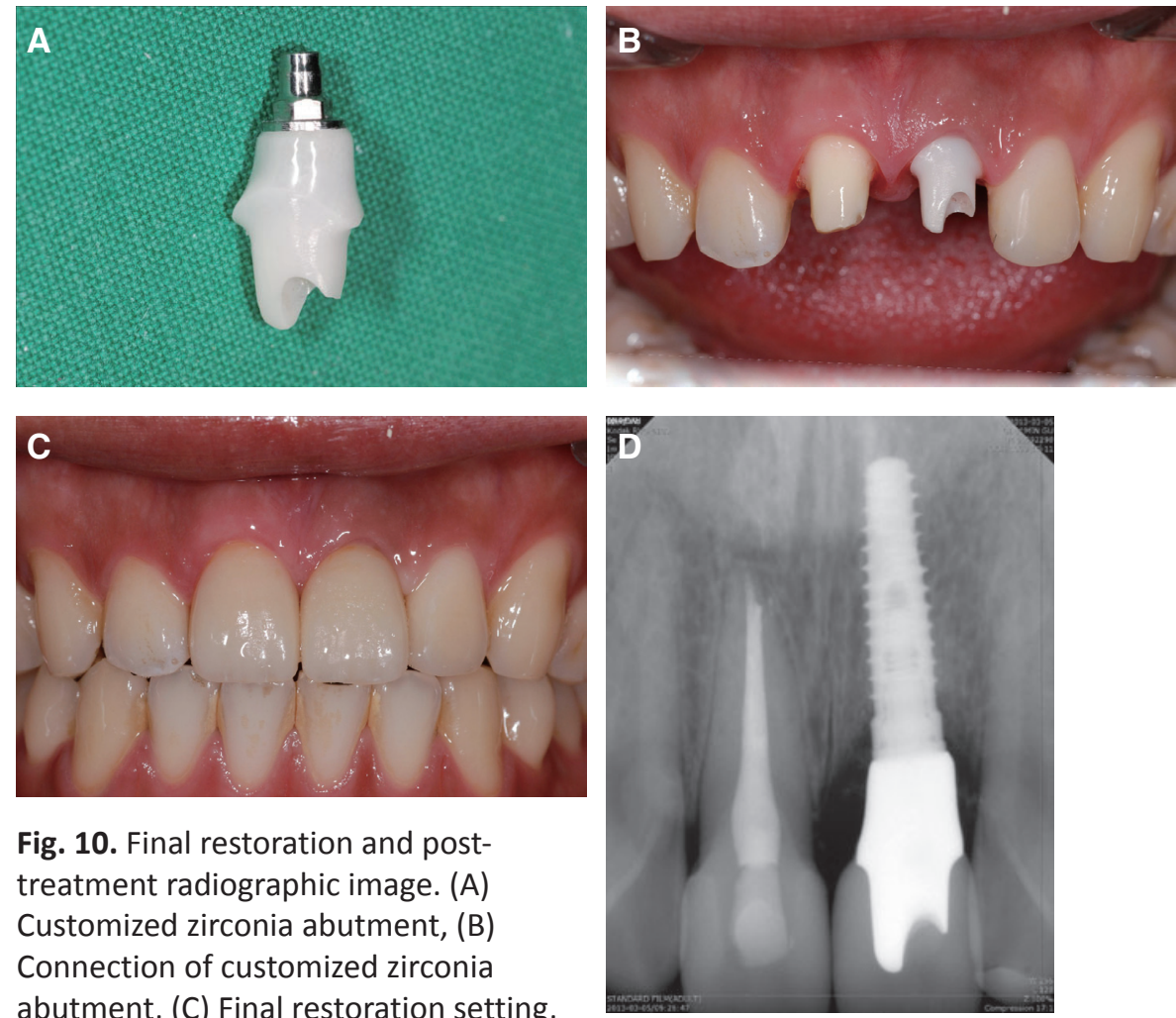

Fig. 10. Final restoration and posttreatment radiographic image. (A) Customized zirconia abutment, (B) Connection of customized zirconia abutment, (C) Final restoration setting, (D) Periapical standard radiographic image.
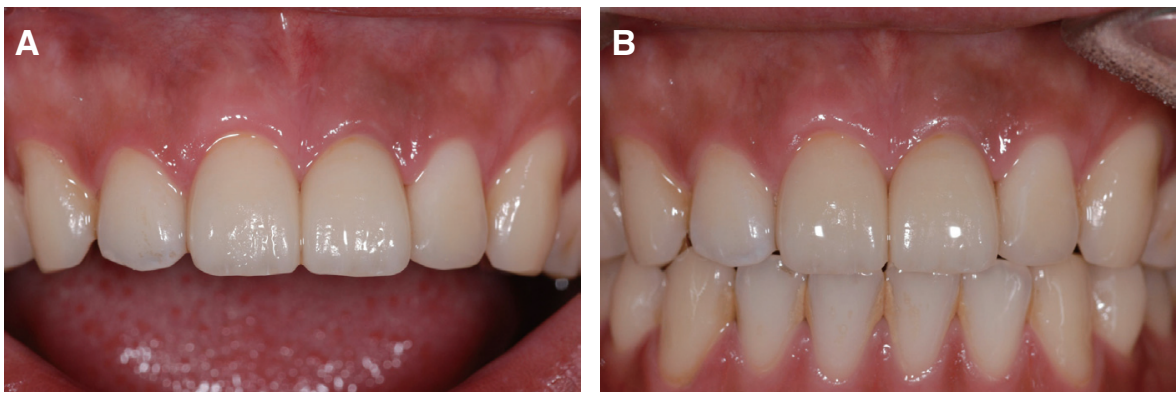

Fig. 11. Follow-up check. (A) 2 weeks after final restoration setting, (B) 6 months after final restoration setting.

최종 모형상에서 상악 좌측 중절치 임플란트의 맞춤 형 지르코니아 지대주(Zirconia Myplant)를 제작한 후 $30 \mathrm{Ncm}$ 의 힘으로 체결하였다. 좌우측 중절치 모두 완전 도재관(IPS e.max Press)을 레진시멘트(RelyX Unicem) 를 이용해 접착하였다(Fig. 10). 발치 전의 치아주위 경, 연조직이 즉시 임플란트 식립 및 보철수복으로 인해 잘 유지되어 연조직 및 최종 보철물이 인접치아와 조화로 운 모습을 보이고 있다.

이후 2주, 6 개월 추적 관찰하였으며, 지속적으로 정기 검진 예정이다(Fig. 11).

\section{3. 증례 3}

1) 환자 개요 및 치료 계획

상기 환자는 56세 남자 환자로 상악 우측 중절치가 흔 들리고 아프다는 주소로 내원하였다. 약 2년 전 식사 중 젓가락을 씹어 주소 부위에 통증 및 동요도가 있었으나, 타 치과에서 경과 관찰을 하던 중, 약 보름 전부터 통증 과 동요도를 인지하여 내원하였다. 임상소견상 2도의 동요도를 보였으며, 농이 배출되고 있었다. 방사선 사진 상, 치근단 $1 / 3$ 부위의 파절을 보였다(Fig. 12). 

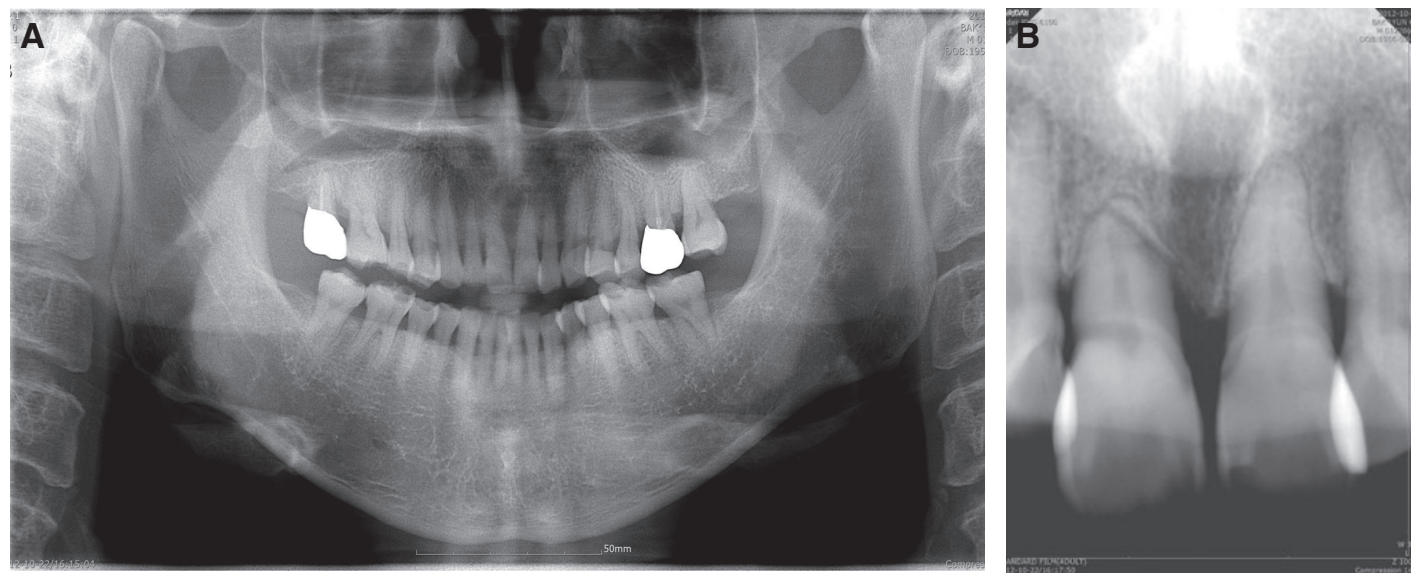

Fig. 12. Pre-operative radiographic image. (A) Panoramic radiographic image, (B) Periapical standard radiographic image.
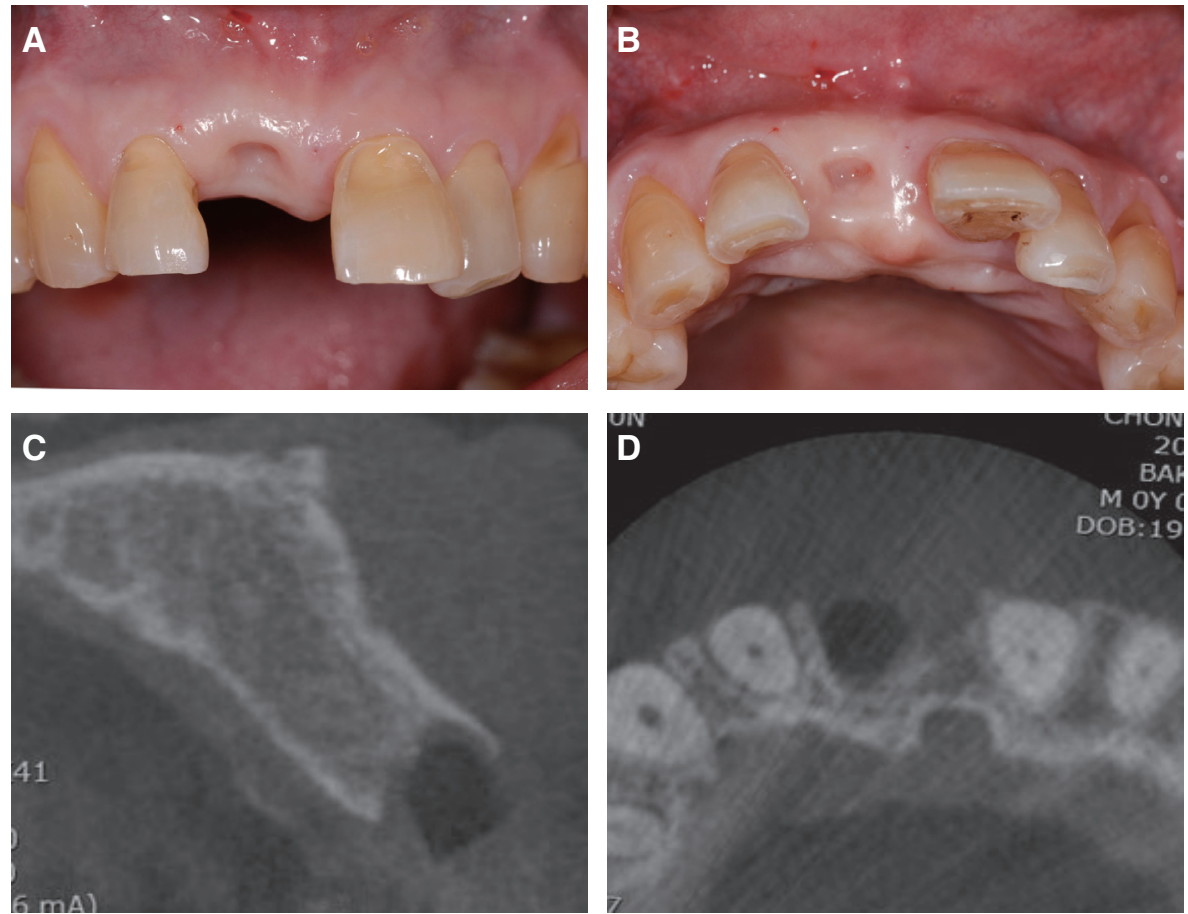

Fig. 13. Pre-operative intraoral photo and radiographic image. (A) Intraoral photo: frontal view, (B) Intraoral photo: occlusal view, (C) Sagittal view on CBCT, (D) transverse view on CBCT.

상악 우측 중절치는 발치 후 골유도재생술을 동반한 임플란트 식립 및 완전도재관으로 수복하기로 하였고, 좌측 중절치의 치경부 마모부위는 레진을 이용해 충전 하기로 계획하였다.

\section{2) 임플란트 식립 및 골유도재생술}

상악 우측 중절치의 발치 2개월 후 임플란트 식립 전 상태이다(Fig. 13). 방사선 소견상 순측 치조골이 많이
소실된 상태였다.

소대절제술을 시행하고, 직경 $4.1 \mathrm{~mm}$, 길이 $12 \mathrm{~mm}$ 의 임플란트(Bone Level Implant-SLActive, Straumann, Waldenburg, Switzerland)를 식립하였다. 하악 우측 하 악지에서 채취한 자가골과 이종골(Bio-Oss)을 $1: 1$ 로 섞어 순측 골결손부에 적용하고, Fibrin glue (Tissel)을 이용하여 이식부를 고정하였으며, 차폐막(Bio-Gide)을 덮어 골유도재생술을 시행하였다(Fig. 14). 

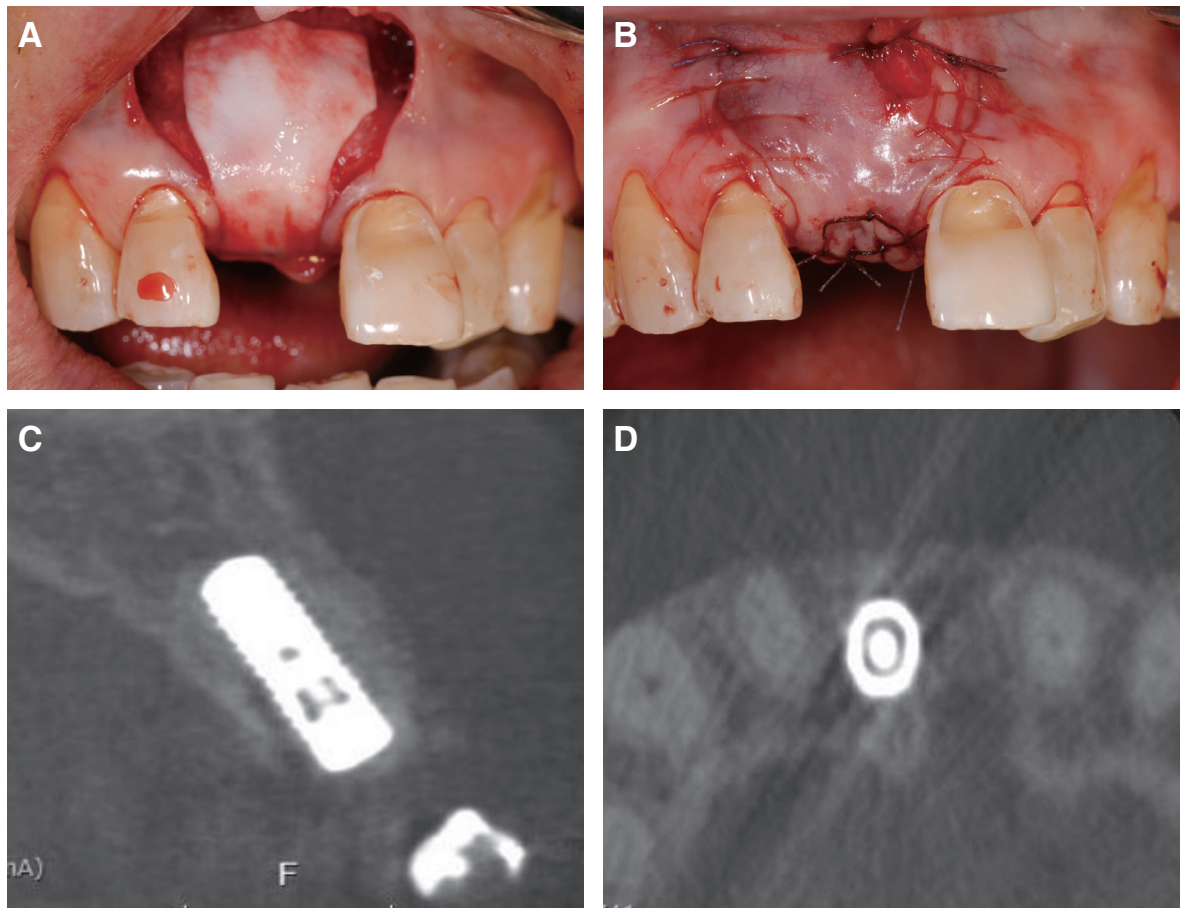

Fig. 14. Implant installation and post-operative radiographic image. (A) Guided bone regeneration (GBR), (B) Closed primary suture, (C) Sagittal view on $C B C T$, (D) Transverse view on CBCT.

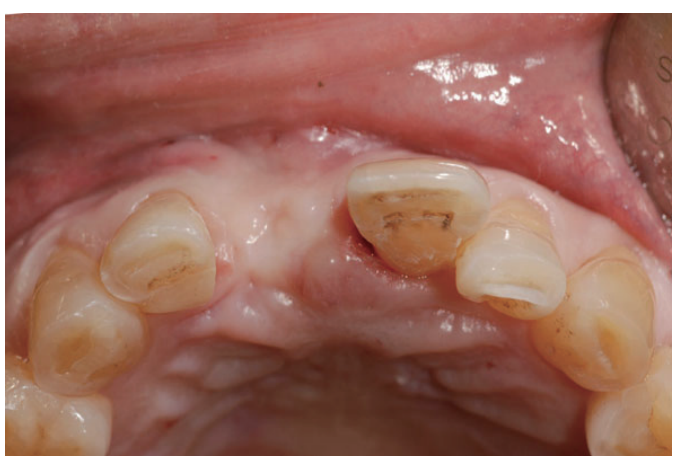

Fig. 15. 5 months after implant installation and GBR.

술 후 경과 관찰 중, 1987년 Seibert 와 Cohen 이 언급 한 치관-치근쪽 치조제 높이는 정상이나 협설측 소실을 보이는 I급 치조제 결손이 보였다(Fig. 15). 보다 심미적 인 결과를 위해 결합조직이식술이 필요할 것으로 생각 되었다.

3) 연조직 증대술 및 임시 보철물 장착

임플란트 식립 후 5 개월에 구개측 vascularized interpositional periosteal-connective tissue (VIP-CT) 피판을
이용하여 연조직 증대술을 시행하였다(Fig. 16).

연조직 증대술 후 2개월, 임플란트 식립 후 7개월에 치조제 결손부가 심미적으로 많이 개선된 모습을 보였 다(Fig. 17).

이후 2차 수술을 시행하고 ISQ 값이 80을 나타내어 임플란트에 연결된 임시 보철물을 제작하였다. 이후 연 조직 형성을 위해 임시 보철물을 주기적으로 수정해 주 었다(Fig. 18).

4) 최종 보철물 완성 및 정기 검진

2차 수술 2개월(임플란트 식립 9개월) 후, 최종 보철물 을 위한 인상을 채득하였다(Fig. 19).

맞춤형 지르코니아 지대주(Zirconia Myplant)를 30 $\mathrm{Ncm}$ 의 힘으로 체결하였다. 지르코니아 코어(ICE Zirkon Translucent, Zirkonzahn, Bruneck, Italy)를 가 지는 완전도재관을 제작한 후, 내면을 tribochemical coating (Rocatec, 3M ESPE) 처리하여, 레진시멘트 (Permacem 2.0, DMG, Hamburg, Germany)를 이용해 접착하였다. 좌측 중절치의 치경부 결손 부위는 레진 (Filtek Z250, 3M ESPE)으로 충전하였다(Fig. 20). 

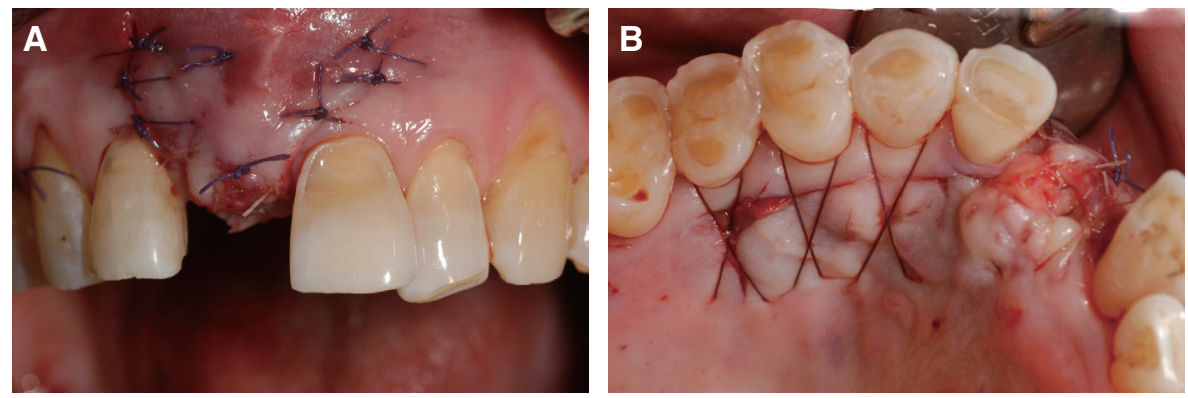

Fig. 16. Soft tissue augmentation with VIP-CT flap. (A) Frontal view, (B) Palatal view.
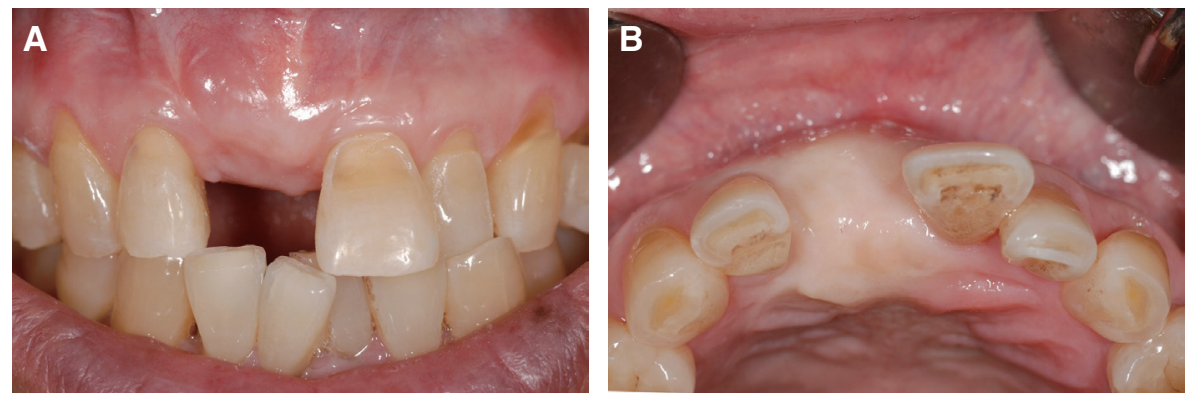

Fig. 17. Improved gingival contour. (A) Frontal view, (B) Occlusal view.
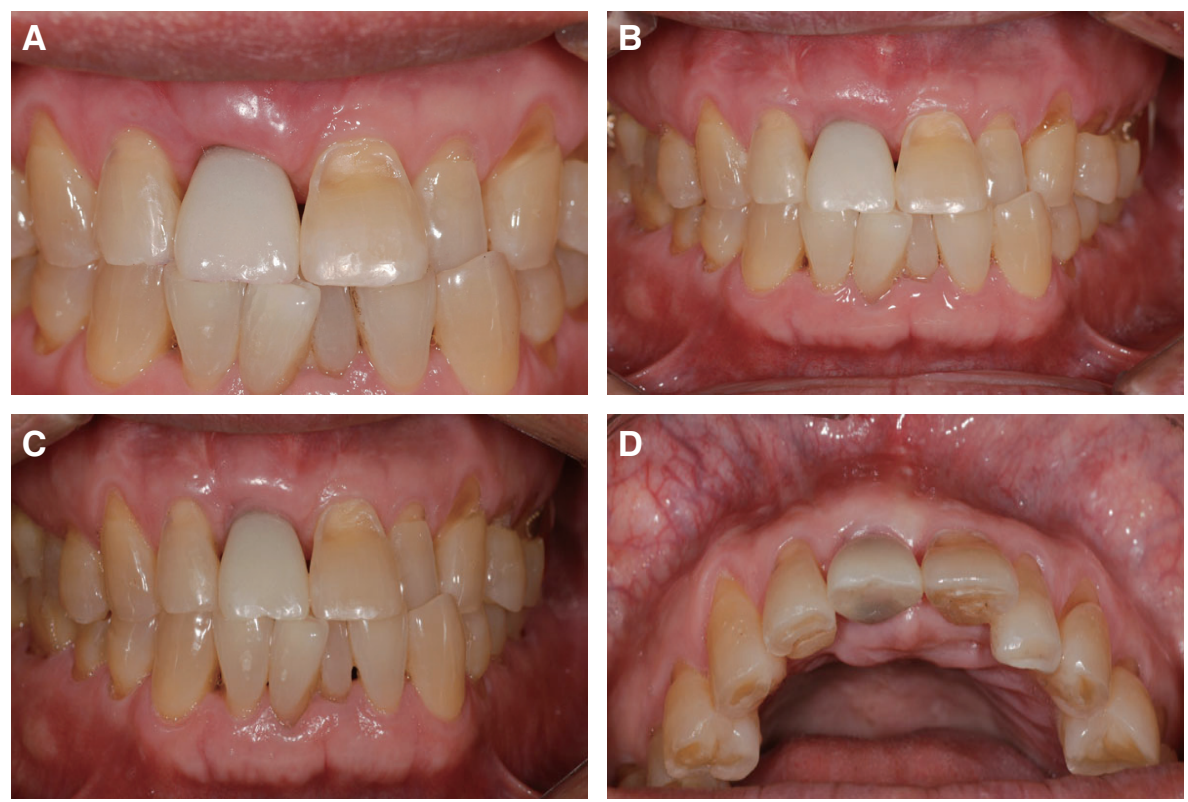

Fig. 18. Provisional restoration. (A) Initial placement of provisional restoration, (B) 4 weeks after provisional restoration setting, (C) 8 weeks after provisional restoration setting: frontal view, (D) 8 weeks after provisional restoration setting: occlusal view. 

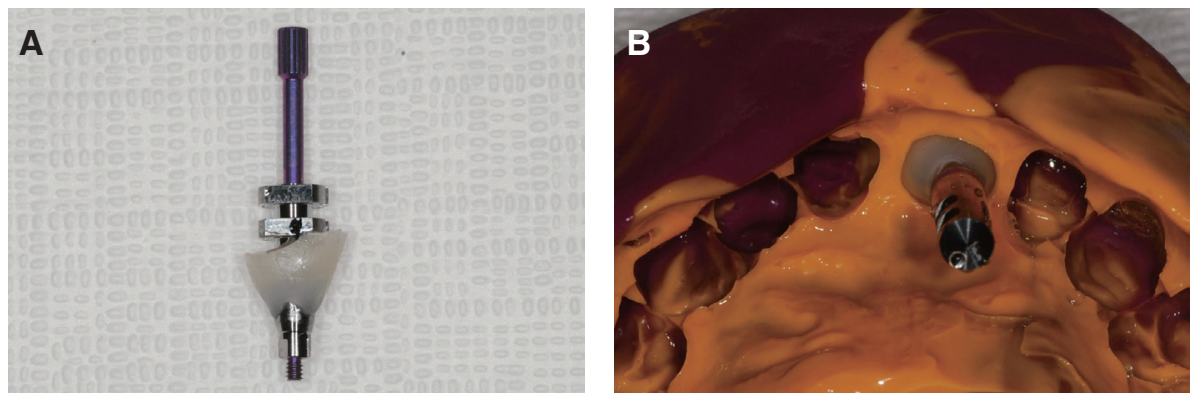

Fig. 19. Final impression taking. (A) Customized impression coping, (B) Impression with customized impression coping for final restoration.
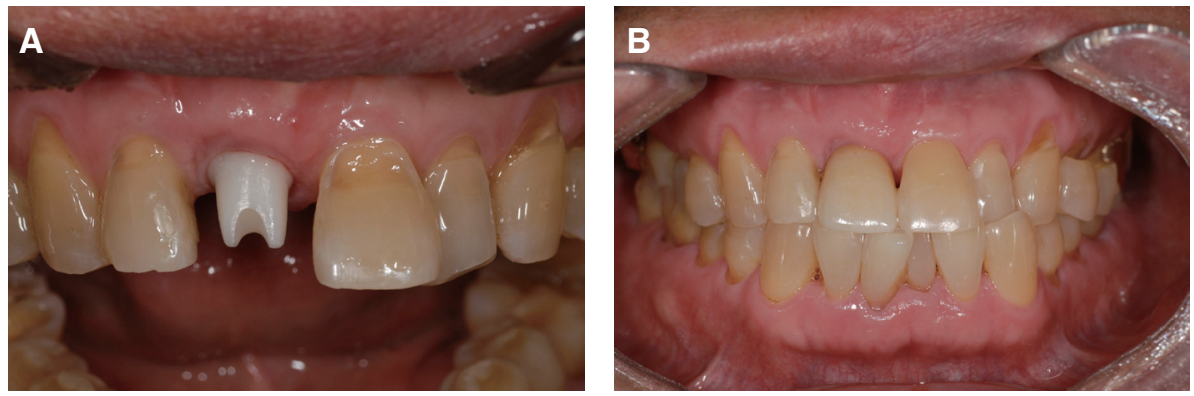

Fig. 20. Final restoration. (A) Connection of customized zirconia abutment, (B) Final restoration setting.

\section{고찰}

상악 전치부는 발치 후 급속한 치조골 흡수가 나타난 다. 이런 경우 심미적 임플란트 수복을 위해 골 결손부 의 경조직 증강술이 필요하다. 이에, 본 증례는 모두 차 단막을 이용한 골유도 재생술을 사용하였다. 골유도 재 생술은 차단막으로 공간을 확보하여 신생골의 형성을 유도하는 처치 방법으로, 많은 선학들의 연구에서 성공 적인 치료를 보였다. ${ }^{8-10}$ 이러한 노력에도 불구하고 증례 3에서는 Seibert 와 Cohen ${ }^{7}$ 이 언급한 I급 치조제 결손을 보였다. I급 치조제 결손은 치관-치근쪽 치조제 높이는 정상이나 협설측 소실을 보이는 것으로, 본 증례에서는 VIP-CT flap을 이용해 극복하였다.

맞춤형 임플란트 지대주에 관한 많은 연구가 있어 왔 다. ${ }^{11-13}$ 맞춤형 임플란트 지대주는 종래에 임플란트 위치 가 이상적이지 않거나, 치은 연하로 깊게 식립된 경우에 만 주로 사용되어져 왔다. 하지만, 맞춤형 임플란트 지 대주는 그 밖에도 개개의 치은형태에 맞는 지대주 제작 이 가능하다는 점과 치경부 출현각(emergence profile) 의 재현이 자유롭고, 지대주간 장축을 일치시킬 수 있다 는 장점에 힘입어 심미성을 요구받는 전치부 뿐 아니라, 구강위생 증진을 위해 구치부에서도 근래에 들어 그 사 용이 증가하고 있다.

Glauser 등 ${ }^{14}$ 은 단일치아 수복에서 평균 49.2개월 동
안 지르코니아 지대주의 파절이 없었으며, Yildrim 등 ${ }^{15}$ 은 전부도재관으로 수복한 증례에서 5년 이상 지대주의 파절 없이 사용하였음을 보고하였다. 본 증례는 장기간 조정한 임시보철물의 치경부 출현각을 맞춤형 인상 코 핑을 이용해 최종모형에 옮기고, ${ }^{2}$ 맞춤형 지르코니아 지 대주를 제작해 환자에게 재현함으로써, 임시보철물 단 계에서 형성된 치은의 형태가 최종보철물 장착 후에도 유지되도록 하였다.

증례 2에서는 즉시 임플란트 식립 후 즉시 임시보철물 을 제작했다. 이는 치료 술식 및 기간을 단축시키고 자 연치아 위치에 임플란트를 식립할 수 있다는 장점이 있 으며 주변 골을 보존하고 연조직의 심미성 면에서도 유 리하다는 장점이 있다. ${ }^{16} \mathrm{Tan}$ 등 $^{17}$ 은 즉시 임플란트 식 립 시 2년 생존율은 $98.4 \%$ 에 이른다고 하였다. 2003년 Calandiello 등 ${ }^{3}$ 은 즉시하중 임플란트의 평균 초기 ISQ 가 76이었고, 최소 수치가 58이었다고 보고하였으며, 2003년 Glauser 등은 초기 ISQ가 71이었다고 하였다. 본 증례는 ISQ가 68을 나타내어 임시보철물을 수술과 함께 연결하였다.

본 증례들은 비록 단기간의 추적 검사를 시행하였다 는 한계가 있으나, 전치부 임플란트가 부가적 수술과 더 불어 임시보철물의 지속적 조정 및 맞춤형 지대주를 이 용함으로써 기능적 심미적으로 만족할 만한 결과를 얻 을 수 있음을 보여준다. 


\section{결론}

상실된 상악 전치부를 임플란트를 이용해 심미적으로 수복하는 것은 어렵다. 적절한 경, 연조직 증대술을 동 반한 주의 깊은 수술과 더불어, 조화롭고 자연스러운 연 조직 형성을 돕는 장기적인 임시보철물은 많은 도움이 된다. 이렇게 형성된 연조직의 모양은 맞춤형 인상 코핑 및 맞춤형 지대주를 사용하여 최종 보철물에 재현될 수 있다. 향후 지속적인 관찰과 관리가 이루어진다면, 좋은 예후를 보일 것이라고 사료된다.

\section{References}

1. Ericsson I, Berglundh T, Marinello C, Liljenberg $\mathrm{B}$, Lindhe J. Long standing plaque and gingivitis at implant and teeth in the dog. Clin Oral Implant Res 1992;3:99-103.

2. Hinds KF. Custom impression coping for an exact registration of the healed tissue in the esthetic implnt restoration. Int J Periodontics Restorative Dent 1997;17:584-91.

3. Calandriello R, Tomatis M, Rangert B. Immediate functional loading of Brånemark system implants with enhanced initial stability: a prospective 1- to 2-year clinical and radiographic study. Clin Implant Dent Relat Res 2003;5:10-20.

4. Glauser R, Lundgren AK, Gottlow J, Sennerby L, Portmann M, Ruhstaller P, Hämmerle CH. Immediate occlusal loading of Brånemark TiUnite implants placed predominantly in soft bone: 1-year results of a prospective clinical study. Clin Implant Dent Relat Res 2003;5:47-56.

5. Bornstein MM, Hart CN, Halbritter SA, Morton D, Buser D. Early loading of nonsubmerged titanium implants with a chemically modified sand-blasted and acid-etched surface: 6-month results of a prospective case series study in the posterior mandible focusing on peri-implant crestal bone changes and implant stability quotient (ISQ) values. Clin Implant Dent Relat Res 2009;11:338-47.

6. Rodrigo D, Aracil L, Martin C, Sanz M. Diagnosis of implant stability and its impact on implant survival: a prospective case series study. Clin Oral Implants Res 2010;21:255-61.
7. Seibert JS, Cohen DW. Periodontal considerations in preparation for fixed and removable prosthodontics. Dent Clin North Am 1987;31:529-55.

8. Schliephake H, Neukam FW, Scheller H, Bothe KJ. Local ridge augmentation using bone grafts and osseointegrated implants in the rehabilitation of partial edentulism: preliminary results. Int J Oral Maxillofac Implants 1994;9:557-64.

9. Mayfield L, Nobréus N, Attström R, Linde A. Guided bone regeneration in dental implant treatment using a bioabsorbable membrane. Clin Oral Implants Res 1997;8:10-7.

10. Hämmerle $\mathrm{CH}$, Jung RE. Bone augmentation by means of barrier membranes. Periodontol 2000 2003;33:36-53.

11. Jemt T. Customized titanium single-implant abutments: 2-year follow-up pilot study. Int J Prosthodont 1998;11:312-6.

12. Lang LA, Sierraalta M, Hoffensperger M, Wang RF. Evaluation of the precision of fit between the Procera custom abutment and various implant systems. Int J Oral Maxillofac Implants 2003;18:652-8.

13. Kim S, Kim HI, Brewer JD, Monaco EA Jr. Comparison of fracture resistance of pressable metal ceramic custom implant abutments with CAD/ CAM commercially fabricated zirconia implant abutments. J Prosthet Dent 2009;101:226-30.

14. Glauser R, Sailer I, Wohlwend A, Studer S, Schibli M, Schärer P. Experimental zirconia abutments for implant-suppoted single-tooth restorations in esthetically demanding regions; 4-year results of a prospective clinical study. Int J Prosthodont 2004;17: 285-90.

15. Yildirim M, Edelhoff D, Hanisch O, Spiekermann H. Ceramic abutments-a new era in achieving optimal esthetics in implant dentistiry. Int J Periodontics Restorative Dent 2000;20:81-91.

16. Chen ST, Wilson TG Jr, Hämmerle CH. Immediate or early placement of implants following tooth extraction: review of biologic basis, clinical procedures, and outcomes. Int J Oral Maxillofac Implants 2004;19:12-25.

17. Tan WL, Wong TL, Wong MC, Lang NP. A systematic review of post-extractional alveolar hard and soft tissue dimensional changes in humans. Clin Oral Implants Res 2012;23:1-21. 


\section{맞춤형 지르코니아 지대주와 완전도재관을 이용한 상악 전치부 임플란트 보철 수복}

김자영 ${ }^{1}$, 서재민 ${ }^{2 *}$

${ }^{1}$ 서남대학교 의과대학 예수병원 치과학교실

${ }^{2}$ 전북대학교 치의학전문대학원 치과보철학교실 및 구강생체과학연구소

상악 전치부에 임플란트를 이용해 심미적으로 수복 하는 것은 많은 어려움이 따른다. 이는 치조골 흡수와 치간 유두 수 축 등과 같은 임플란트 주변 경, 연조직 문제와 금속지대주 및 금속도재관의 변연노출과 낮은 광투과도 등의 보철적 한 계 때문이다. 이에 본 증례에서는 경, 연조직의 증대술 및 성형술, 발치 후 즉시 식립 등과 함께 임시수복물의 장기간 사 용 및 수정으로 임플란트 주위 연조직의 형태와 건강을 형성한 후, 맞춤형 인상 코핑을 사용하여 이를 최종 모형에 재 현하였다. 또한 맞춤형 지르코니아 지대주와 완전 도재관을 이용해 최종 수복함으로써 기능적이고 심미적인 결과를 얻 었기에 이를 보고하고자 한다.

(구강회복응용과학지 2014;30(1):81-92)

주요어: 맞춤형 인상 코핑; 완전도재관; 임플란트; 지르코니아 지대주 